\title{
NEW EXPERIMENTAL SULFOALUMINATE CLINKERS FROM NATURAL RAW MATERIAL MIXTURES
}

\author{
TIMEA HALMAGYI ${ }^{a}$, EMILIA MOSONYI ${ }^{b, *}$, JÓZSEF FAZAKAS ${ }^{a}$
}

\begin{abstract}
The paper presents new different raw materials mixtures which should lead to the theoretical mineralogical compositions of sulfoaluminate belitic (SAB) clinkers. The mixtures, composed of limestone, gypsum, clay, diatomite, basaltic scoria, volcanic tuff and red mud (bauxite ore processing by-product), have been burned at 1220,1240 and $1260{ }^{\circ} \mathrm{C}$ for one hour in an electrical laboratory furnace, then quenched in fresh air. The resulted clinker samples were studied in thin sections under a polarizing petrographic microscope for clinker structure, microtexture and mineralogical association. The mineralogical assemblage assessment by XRD analyses was completed. The sample XRD patterns (processed by Match software and pdf2 database) have been allowed a qualitative and a semiquantitative estimation (external standard method) of the main mineralogical compounds: $\mathrm{C}_{2} \mathrm{~S}$ (belite), $\mathrm{C}_{4} \mathrm{AF}$ (brownmillerite), $\mathrm{C} \overline{\mathrm{S}}$ (anhydrite), $\mathrm{C}_{4} \mathrm{~A}_{3} \overline{\mathrm{S}}$ (sulfoaluminate), proper for sulfoaluminate belitic clinkers. The identified minor and secondary mineral phases were: alkali ( $\mathrm{Na}, \mathrm{K}, \mathrm{Na}-\mathrm{K}$ ) sulfates, natroalunite $\left(N_{K A} A_{6} \bar{S}\right)$, limeite $(C)$, periclase $(M)$, gehlenite $\left(C_{2}\left(A_{1}\right.\right.$ $\left.{ }_{x}, \mathrm{M}_{\mathrm{x}}\right)(\mathrm{AS})$ ). The following abbreviations were used: $\mathrm{C}=\mathrm{CaO} ; \mathrm{S}=\mathrm{SiO}_{2} ; \mathrm{A}=\mathrm{Al}_{2} \mathrm{O}_{3}$; $\mathrm{F}=\mathrm{Fe}_{2} \mathrm{O}_{3} ; \overline{\mathrm{S}}=\mathrm{SO}_{3} ; \mathrm{H}=\mathrm{H}_{2} \mathrm{O} ; \mathrm{M}=\mathrm{MgO} ; \mathrm{N}(\mathrm{K})=\mathrm{Na}_{2} \mathrm{O}\left(\mathrm{K}_{2} \mathrm{O}\right)$.
\end{abstract}

Keywords: Sulfoaluminate belitic clinker, clinker chemistry, raw materials, transmission polarizing microscopy, XRD analyses

\section{INTRODUCTION}

The modern civil engineering requirements impose the obtaining of a new sort of cement which has a good quality, is environmentally friendly and needs low energy consumption. For these reasons, the low energy

${ }^{a}$ Babeş-Bolyai University, Faculty of Chemstry and Chemical Engineering, 11 Arany Janos str., RO-400028, Cluj-Napoca, Romania

b Babeş-Bolyai University, Faculty of Biology and Geology, 1 Kogalniceanu str., RO-400082, Cluj-Napoca, Romania

Corresponding author: emilia.mosonyi@ubbcluj.ro 
cement manufacturing is attractive from economic and ecological points of view. These cements could be used where there are needs of high early strength or expansion compensation, but increased durability.

The low energy clinkers/cements comprise those materials which belong to the $\mathrm{CaO}-\mathrm{SiO}_{2}-\mathrm{Al}_{2} \mathrm{O}_{3}-\mathrm{Fe}_{2} \mathrm{O}_{3}-\mathrm{CaSO}_{4}$ system and they are mainly sulfoaluminate belite and sulfoferroaluminate belite cements [1] They may be manufactured both from natural raw materials and raw materials mixed with industrial by-products or industrial waste, by firing at lower temperature than Portland cement clinker.

In the $\mathrm{CaO}-\mathrm{Al}_{2} \mathrm{O}_{3}-\mathrm{SiO}_{2}-\mathrm{CaSO}_{4}$ system there are two ternary compounds: the calcium sulfoaluminate $\left(\mathrm{C}_{4} \mathrm{~A}_{3} \overline{\mathrm{S}}\right)$ and calcium sulfosilicate ("sulfo- spurrite" $\mathrm{C}_{5} \mathrm{~S}_{2} \overline{\mathrm{S}}$ ), the later hydraulically inactive [2].

Data about chemical composition, manufacturing and features of sulfoaluminate belitic (SAB) cement may be found in cement related literature $[3,4,5,6,7]$. $A$ large variety of cements based on $\mathrm{C}_{4} \mathrm{~A}_{3} \overline{\mathrm{S}}$ were experimented on in China and used mainly for concrete preparation. These were standardized and named as "Third Cement Series" [8].

The "Third Series" of cements were developed in China, those sulfoferritic since 1972 and those sulfoferroaluminate types since 1983, using Fe-rich raw materials. These cements have special features such as: quick setting time, good impermeability, rapid strength development even at low temperature $[9,10]$.Their main mineral phases are: belite $\left(C_{2} S\right), C_{4} A_{3} \bar{S}$ and tetracalcium ferroaluminate $\left(\mathrm{C}_{4} \mathrm{AF}\right)$, in different ratios. Such clinker composition comprises: $53 \% \mathrm{C}_{4} \mathrm{~A}_{3} \overline{\mathrm{S}}, 18 \% \mathrm{C}_{2} \mathrm{~S}, 12 \% \mathrm{C}$ and $15 \% \mathrm{C}_{4} \mathrm{AF}$ (2\% residue) [4].The main mineral phases of SAB cements are: $\beta-\mathrm{C}_{2} \mathrm{~S}(25-65 \%), \mathrm{C}_{4} \mathrm{~A}_{3} \overline{\mathrm{S}}(10-20 \%)$, $\mathrm{C}_{4} \mathrm{AF}(15-40 \%)$ and sometimes, $\mathrm{C} \overline{\mathrm{S}}(10-20 \%)$, depending on the $\mathrm{SO}_{3}$-content of raw mixture [11, 12]. Different mineral proportions of such clinkers results cements with different hydraulic properties. The tetracalcium ferroaluminate $\left(\mathrm{C}_{4} \mathrm{AF}\right)$, formed at lower temperatures $\left(120{ }^{\circ} \mathrm{C}\right)$, due to its solid phase reactions is much more reactive than the similar mineral from the Portland cement clinker, which is generated from a melt by late crystallization [13].

The calcium sulfoaluminate, $\mathrm{C}_{4} \mathrm{~A}_{3} \overline{\mathrm{S}}$, known also as „Klein compound” $[14,15,16,17,18,19,20]$, has a similar structure to the natural mineral haüyn or to another mineral, sodalite and can already be sinterized at about $1300{ }^{\circ} \mathrm{C}$ beside belite $\left(\beta-C_{2} S\right)$ and ferrite $\left(C_{4} A F\right)$ [21]. The $C_{4} A_{3} \bar{S}$ forms at about $1250{ }^{\circ} \mathrm{C}$ and is stable up to the $1350{ }^{\circ} \mathrm{C}$ [9]. High sulfoaluminate contents imply a high early strength of cement binder, chemical corrosion resistance and controlled expansion. [8, 22]. Using gypsum as a mineralizer for the stabilization of the $\beta-C_{2} \mathrm{~S}$ polymorph in the $\mathrm{CaO}-\mathrm{Al}_{2} \mathrm{O}_{3}-\mathrm{SiO}_{2}$ system the low temperature clinker resulted, in which the main mineral components were $\beta-C_{2} S$ and $C_{4} A_{3} \bar{S}[23]$. 
Obviously, the burning temperature of SAB clinkers is between 1200$1350^{\circ} \mathrm{C}$, depending on the raw mixture composition and minor element impurities, such as: phosphates, sulfates, borates and different oxides. The firing temperature of such clinkers may be low, of about $1200-1250{ }^{\circ} \mathrm{C}$, when waste materials (blast furnace slag, phosphogypsum, pyrite ash) containing many minor elements are used for clinker recipes. The oxide-type impurities work as mineralizers $[6,9]$ in the sintering process. The energy saving clinkers' manufacturing takes place at temperatures of about $200-300^{\circ} \mathrm{C}$ lower than those Portland cement needs [21, 24]. The energy-saving advantage is accompanied by an ecological one, due to the lowering of $\mathrm{CO}_{2}$ (greenhouse) gas emissions and reusing of industrial waste materials, which partly can replace the natural raw materials or may be used as cement mineral additions.

During sulfoaluminate cements manufacturing were established a diminishing with $43 \%$ the $\mathrm{CO}_{2}$ emissions [4], or with $20-30 \%$ [25] respectively. In the same processes a diminishing with $14 \%$ the specific heat consumption and with about $25 \%$ of the total energy consumption [12] was observed, when compared to the Portland cement technology. Finally a lowering with $40 \%$ of the clinker milling energy (due to more brittle mineral contents) was found, using as reference the same technology data.

The SAB clinkers are environmentally friendly, because their manufacturing needs industrial waste materials, the storage of which may imply environment pollution risks. In the world clinkers sinterized from mixtures containing materials such as: red muds as by-products of bauxite ore preparation [9, 22, 26, 27], fly ash [9, 28, 29, 30], steelmaking slags [22], dust from filters, fluidized bed combustion ash [30], blast furnace ash [31] were investigated.

The hydraulic properties of sulfoferrite cements with increased content of $\mathrm{C}_{4} \mathrm{AF}$ are highly influenced by the applied thermal treatment, mainly by the quenching rate $[11,24]$.

The sulfoaluminate belite and sulfoferroaluminate belite cements may have different applications due to the changing quality and dosage of additions, such as: blast furnace slag, power-station ash [31, 32]. The SAB cements, obtained at low temperatures, are good sulfate- and moderate chloride- resisting binders [33].

The SAB cements are also attractive for their physico - mechanical properties, presenting good early strength.

In the last decades the Lafarge' researchers have also been experimenting with a new class of lower-carbon clinkers, or 'Aether' clinkers $[34,35,36,37]$, based either on sulfoaluminate clinker (SAC) containing 55$75 \%$ ye'elimite $\left(C_{4} A_{3} \bar{S}\right), 15-30 \%$ belite $\left(C_{2} S\right)$ and $3-6 \%$ ferrite $\left(C_{2}(A, F)\right)$ or on ferroaluminate clinker (FAC) containing $45-65 \%$ ye'elimite, $15-35 \%$ belite and $10-25 \%$ ferrite. [38] 
Industrial scale experimental clinkers of such compositions require significantly less calcium carbonate in the kiln feed, and in situ measurements evidenced $\mathrm{CO}_{2}$ savings between 25-30\% [39, 40]. Hydraulic properties of Aether clinkers are based on $\mathrm{C}_{4} \mathrm{~A}_{3} \overline{\mathrm{S}}$, which ensures the reactivity of the binder and the early strength up to seven days before the $\mathrm{C}_{2} \mathrm{~S}$ and the $\mathrm{C}_{4} \mathrm{AF}$ phases take over. The hydration of the latter two phases ensures the final strength of this binder type [41].

The aim of our studies was to continue previous work [42] with testing low energy cement recipes series, comprising natural raw materials and red mud (bauxite ore preparation by-product) from Romania. In these experimental works we used as starting point theoretical mineral compositions of such clinker types, published in the cement literature $[1,4,6]$.

The raw mixture series (samples $1,4,5,6,7,9,10,12$ ), even if of non- reagent- grade kiln feeding compounds, were fired between 1220$1240^{\circ} \mathrm{C}$, then, resulted clinkers were checked for mineral compositions and compared with theoretical low energy clinker compositions.

\section{RESULTS AND DISCUSSION}

The experimental clinker samples were investigated in thin sections by petrographic microscopy, in plane polarized $(1 \mathrm{~N})$ and cross polarized light $(\mathrm{N}+)$. The samples microscopically comprise 2 main components: particles (clusters, nests) of different sizes (200- $250 \mu \mathrm{m})$, and an interstitial partially crystalline component. The particles are composed by lime silicate crystals and the interstitial of light greenish up to green-olive color, contains isotropic sulfoaluminates, dark brownish laths of zoned brownmillerite, isolated or twinned laths of anhydrite, limeite (C), periclase (M).

Frequently, the lime silicate nests and clusters, present complex inner structures with all three belite morphology. (Detailed characterization of observed belites and clinker fabric from these experimental series (clinker samples 2A, 3, 8A, 11A, 11B) were presented in a previous article [42].) There are also pores with circular or elliptical contours, their walls being covered by alkali sulfates and/or anhydrite (see center of Figures 1a, 1b.).

A few studied clinker thin section images may be observed in Figures $1 a, b-4 a, b$.

For all sample thin section microscopic images were taken on same image both in plane polarized light (a) and cross polarized light (b). Few interpretations of microstructures were made after Campbell book. The red colored scale bar from all microscopic images is $50 \mu \mathrm{m}$. 


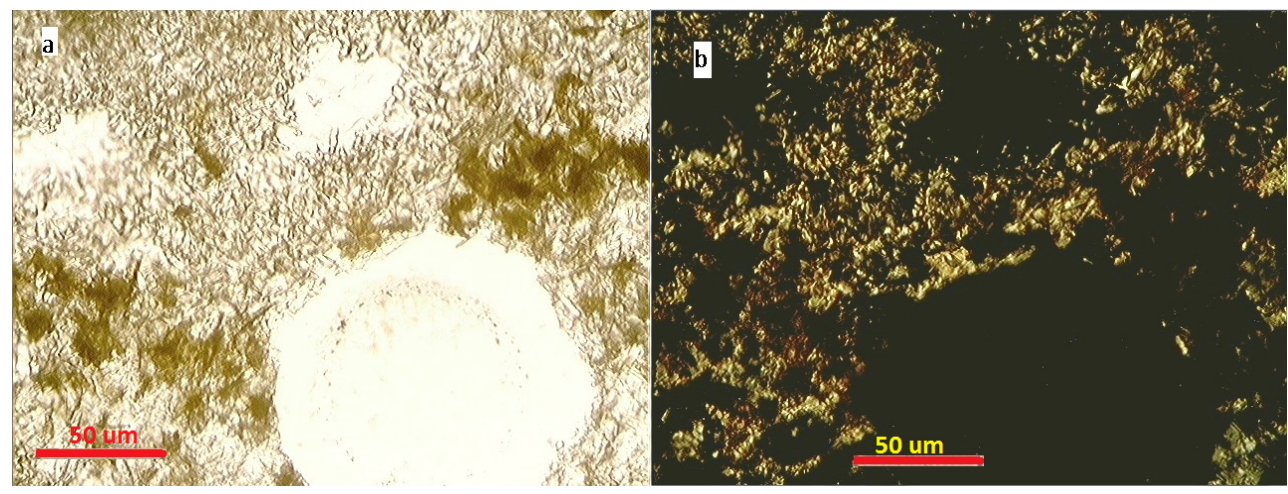

Figure 1. Microscopic image of Sample $7 \mathrm{~A}$, fired at $1240^{\circ} \mathrm{C}$, raw mix containing $4.69 \%$ basaltic scoria. a. $(1 \mathrm{~N})$; b. Same as a., but $\mathrm{N}+$.

In Sample 7A (with raw mixture containing basaltic scoria) with Microscopic images from Figures $1 \mathrm{a}$, there is a greenish- olive interstitial phase as droplets (containing brownish laths and rosettes of brownmillerite needles, greenish sulfoaluminate and twinned laths of colorless anhydrite) between greyish-yellow colored clusters of belite I (presenting two twinning directions in bottom left corner and high relief, and belite developed mainly around pores). There are also: pores $(P)$ coated in inner part by a ring of alkali sulfates (with low relief). Figure $1 \mathrm{~b}$ is the same as Figure $1 \mathrm{a}$, but observed in cross polarized light. There are belitic nests and clusters (presenting yellowish birefringence) sometimes with inner zonal arrangements of belite types [43] like belite I (two directions of twin lamellae) and belite II (one direction of twin lamellae). The interstitials are: brownmillerite with high birefringence (reddish brown), isotropic sulfoaluminate and anhydrite laths beside very low quantity of amorphous phase.

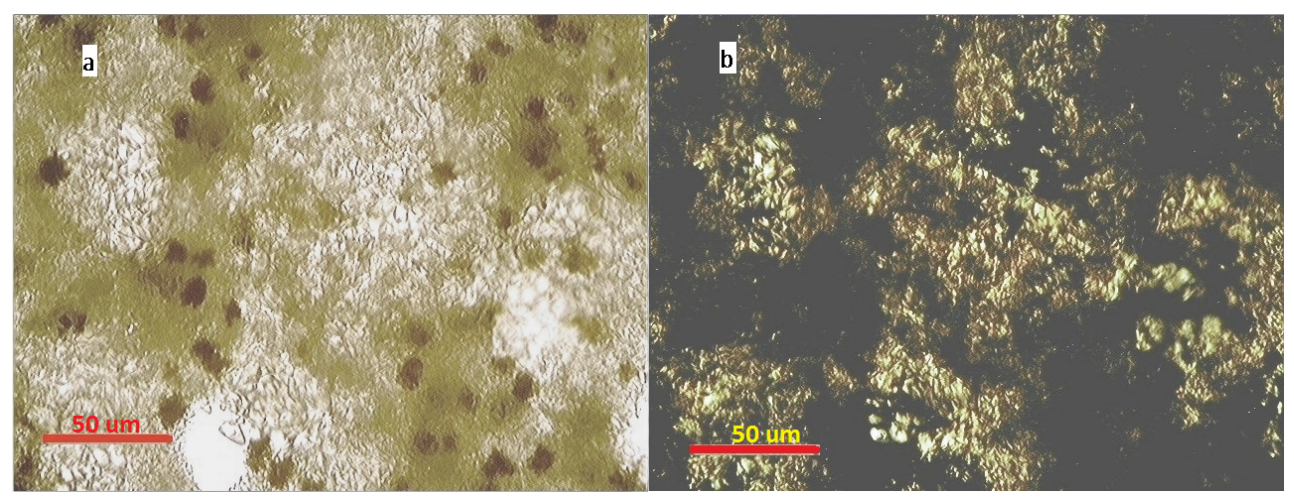

Figure 2. Microscopic images of Sample $6 \mathrm{~A}$, fired at $1240^{\circ} \mathrm{C}$, raw mix recipe containing $7.84 \%$ diatomite: a $(1 \mathrm{~N})$; b. Same as a, but $\mathrm{N}+$, 
In Figures $2 a$ and $2 b$ there are belitic nests and clusters (ex. image centre). In figure $2 a$, around light colored nests there is a cryptocrystalline groundmass, comprising dark brown ferrite rosettes and greenish sulfoaluminate crystals beside rare laths of colorless anhydrite. In cross polarized light $(\mathrm{N}+)$ the sulfoaluminate is isotropic, having an anhydrite corona (light colored, anomalous birefringence, top left corner of b. image). Around pores $(P)$ were also developed ring structures of belite I or belite II.

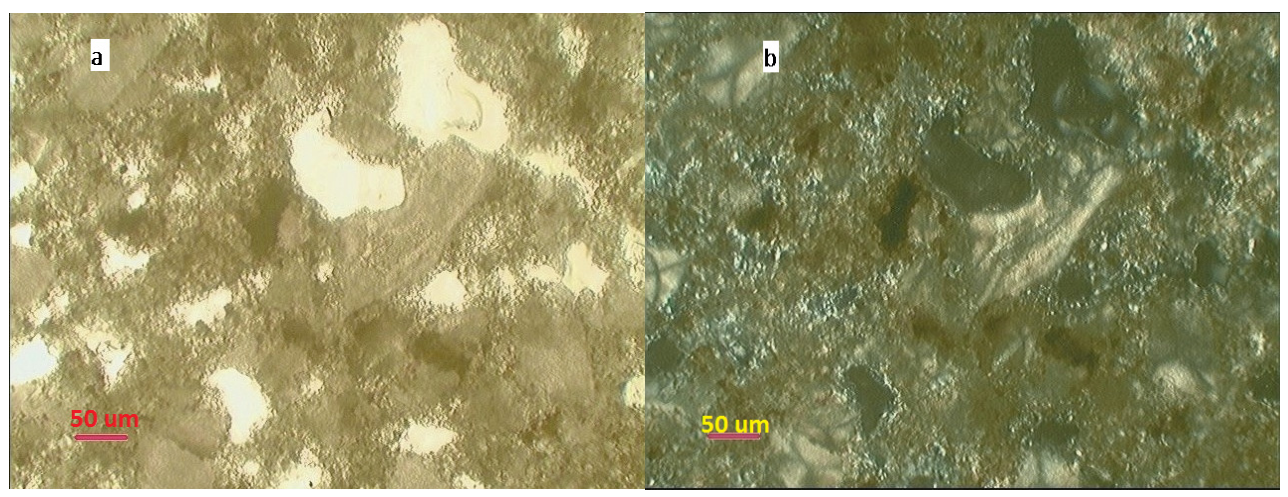

Figure 3. $a(1 \mathrm{~N}), \mathrm{b}(\mathrm{N}+)$ : Microscopic image of Sample 1 (fired at $1220^{\circ} \mathrm{C}$, raw dosages containing $7.09 \%$ clay):

In thin section of Sample 1 (Figure 3) there are many spherolites of belite III (with ondulatory extinction, ex in the center of b., due to the intergrowth of very fine dendritic crystals), presenting zonal microstructure in a.: with darker core zone containing little iron-bearing exsolutions spots and a rim zone corroded by the interstitial brown-greenish colored brownmillerite (which is also zoned compositionally). The matrix corrosion may be interpret as reducing burning conditions.

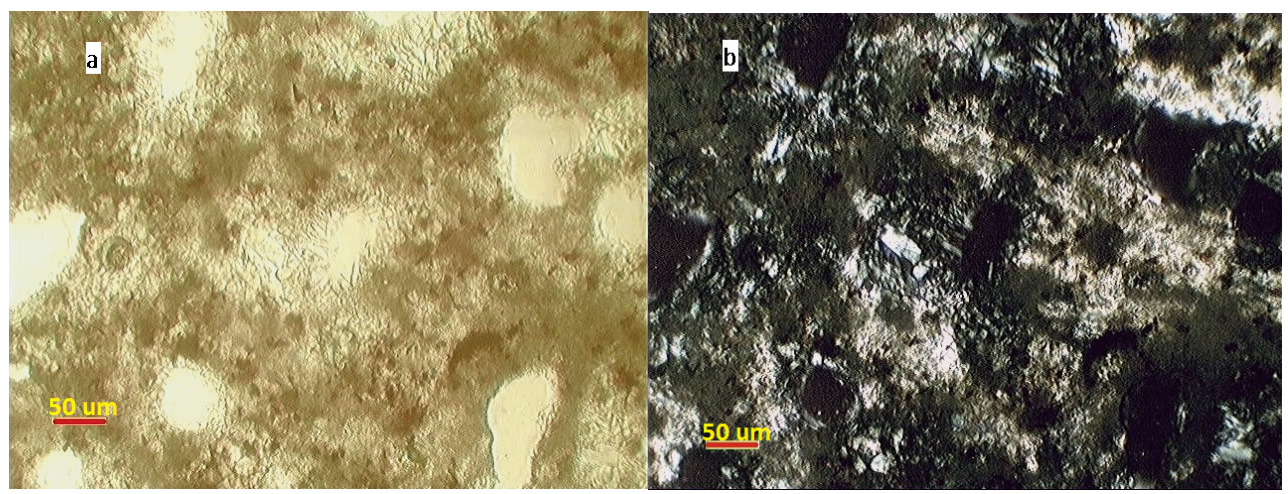

Figure 4. $a(1 \mathrm{~N}), b(\mathrm{~N}+)$. Microscopic image of Sample 12 (burned at $1220^{\circ} \mathrm{C}$, raw mixture containing $2.74 \%$ diatomite). 
Figure 4 is the thin section image of Sample 12 and presents in a, brownish grey colored slightly differentiated interstitial (brown ferrite and greyish sulfoaluminate, which in figure $b$ is almost isotropic) many pores with yellowish- amber colored belite I nest and clusters in a. (belite yellowish- grey color could mean low hydraulic properties). Some belite I nests have in the central part prismatic comb-like arranged relic alite of 30-40um size with grey birefringence and polysynthetic twins (center of image, around pore, in $b$ ) . Sometimes the belitic nests possess prolongations into the matrix ("ragged belite") or present splintery fractures (in the top center of image), specific for the $y$-belite with low hydraulic properties. The ragged belite may be interpreted as slow cooling rate conditions during clinker formation.

The complex inner arrangement of belite types from nests and clusters, chemical zonality of belite, ferrite phases (optically observed as zonal distribution of its colors) and coarse grain size of minerals are all due to a slow diffusion rate during sintering and quenching processes.

Few crystalline phases could not identify under the optical microscope, but were evidenced by XRD analyses, such as alkali ( $\mathrm{Na}, \mathrm{K}, \mathrm{Na}-\mathrm{K}$ ) sulfates, natroalunite $\left(N_{K A_{6}} \bar{S} H\right)$, limeite $(C)$, periclase $(M)$, gehlenite $\left(C_{2}\left(A_{1-x}, M_{x}\right)(A S)\right)$.

The sulfoaluminate, identified in all clinker samples, crystallizes in the cubic system, has high relief, similar to the other lime silicates. It however differs from the other colorless lime sulfoaluminates, described in the cement literature $[23,43,44,45,46]$, because it presents greenishyellow up to olive pleochroic colors (probably due to $\mathrm{Fe}^{2+}$ content, which ions isomorphically replace the $\mathrm{Ca}^{2+}$ or $\mathrm{Fe}^{3+}$ ions which replace $\mathrm{Al}^{3+}$ in the mineral molecule). The correct chemical characterization of this mineral should be done also by SEM-EDX. In this solid solution situation, the correct mineral formula should be written $\mathrm{C}_{4} \mathrm{~A}_{3-x} \mathrm{~F}_{x} \overline{\mathrm{S}}$ [47]. The sulfoaluminate

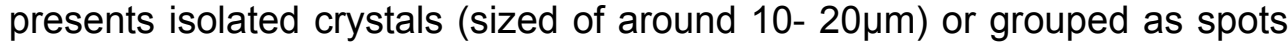
between the glass droplets and brownish ferrite prisms or rosettes.

The XRD patterns of clinkers were interpreted by Match 2.0 software (RIR method, of Chung [48], using I/lc ratio suggested by Wolff and Viser [49]), which permitted a semiquantitative estimation ( $\pm 5 \%$ error) of main and minor crystalline phases, (without amorphous phase) such as those from SAB clinkers. These compositions were comprised in Figure 5 beside the tentative (theoretical) mineral compositions.

In Figure 5 those experimental compositions which are the closest to the theoretical ones are clinker $4 \mathrm{~A}$ (fired at $1240^{\circ} \mathrm{C}$, feeding material containing $2.4 \%$ diatomite), $6 \mathrm{~A}$ (burned at $1240^{\circ} \mathrm{C}$, raw mix containing $7.8 \%$ diatomite), $7 \mathrm{~A}$ (burned at $1240^{\circ} \mathrm{C}$, containing $4.7 \%$ basaltic scoria) and 12 (fired at $1220{ }^{\circ} \mathrm{C}$, raw mix containing $2.7 \%$ diatomite). By using around 23$55 \%$ gypsum in raw mix for all burned samples, a higher anhydrite content 
resulted when compared to theoretical one (more with 2-3\%), the latter possessing good hydraulic properties.

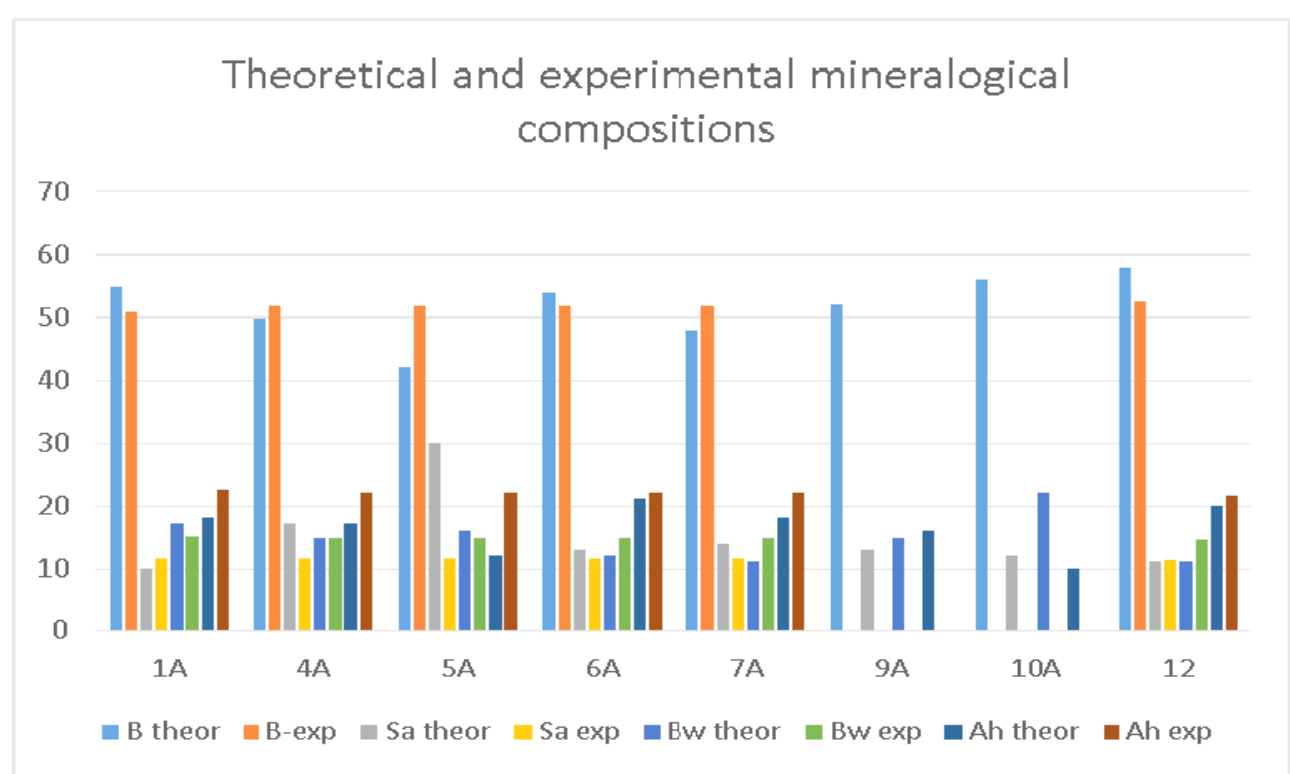

Figure 5. Comparison experimentally tested (XRD) mineralogical compositions with theoretical ones. Sample marked as "A" means clinkering temperature $1240^{\circ} \mathrm{C}$ and name without "A" - clinkering at $1220^{\circ} \mathrm{C}$. Samples $9 \mathrm{~A}$ and $10 \mathrm{~A}$ were not analyzed by $\mathrm{XRD}$, but with optical microscopy. (B- belite, Sa- sulfoaluminate, Ah- anhydrite, Bw- brownmillerite)

The belite contents of experimental clinkers are around $50 \%$, but in samples $1 \mathrm{~A}$ and 12 it appears that the trial compositions were poorer than in theoretical ones. The most belite-rich clinker samples were $4 \mathrm{~A}$ and $7 \mathrm{~A}$, when compared to theoretical compositions, probably explained by optimal $\mathrm{Fe}_{2} \mathrm{O}_{3}(5-7 \%)$ and other different mineralizers' $\left(\mathrm{TiO}_{2}, \mathrm{MgO}\right.$, alkali oxides) bringing material in the raw mix such as volcanic rocks, clay or diatomite. The red mud brings into the raw mix composition of sample 5 a relative high $\mathrm{MgO}$ and $\mathrm{Na}_{2} \mathrm{O}$ content beside optimal $\mathrm{Fe}_{2} \mathrm{O}_{3}$ percent for monoclinic $\beta$ belite stabilization, but this latter clinker sample however contain lower percent (around 10\%) sulfoaluminate than in theoretical composition.

The anhydrite contents present higher values than theoretical compositions.

By firing the presented raw material mixtures clinkers (sample $1 \mathrm{~A}$ $1240^{\circ} \mathrm{C}, 4 \mathrm{~A}-1240^{\circ} \mathrm{C}, 5 \mathrm{~A}-1240^{\circ} \mathrm{C}, 6 \mathrm{~A}-1240^{\circ} \mathrm{C}, 7 \mathrm{~A}-1240^{\circ} \mathrm{C}, 12-1220^{\circ} \mathrm{C}$ ) having a main mineral phase specific to the $S A B$ type resulted. The XRD powder pattern of investigated clinker samples were grouped in the Figure 6. 


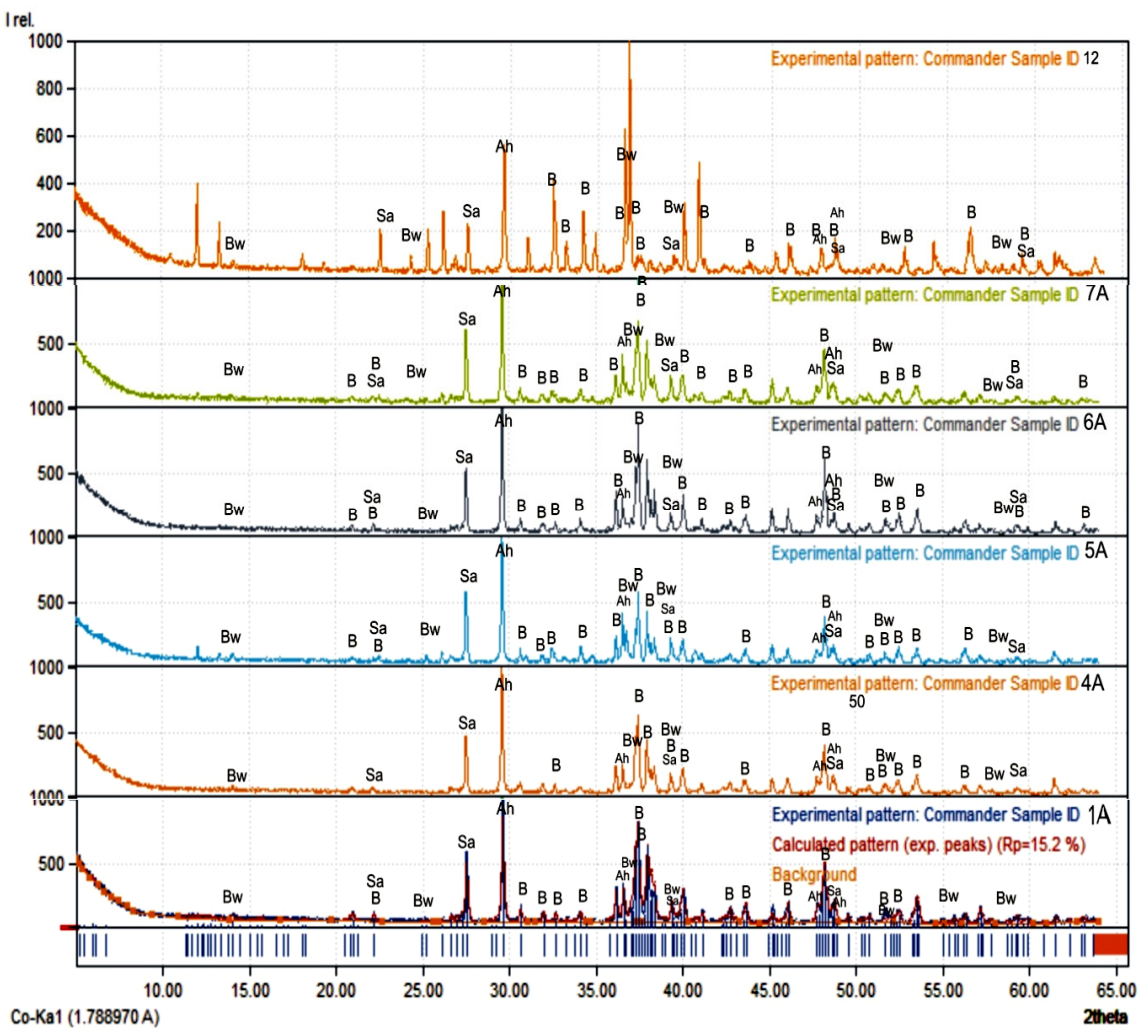

Figure 6. The XRD powder patterns of clinker samples. The mineral abbreviations same as in Figure 5.

Other minor mineral components, unmarked in figure 6 were, in sample 1A: periclase $(M)$, limeite $(C), K_{2} \bar{S}, C_{3} S$; in sample $4 A$ : $C, M, N_{2} \bar{S}$, $\mathrm{K}_{3} \mathrm{NS}_{2}$, gehlenite $\left(\mathrm{C}_{2}\left(\mathrm{~A}_{1-\mathrm{x}}, \mathrm{M}_{\mathrm{x}}\right)(\mathrm{AS})\right)$; in sample $5 \mathrm{~A}: \mathrm{C}, \mathrm{K}_{3} \mathrm{NS}_{2}$; in sample $6 \mathrm{~A}: \mathrm{C}$, $\mathrm{M}, \mathrm{K}_{2} \overline{\mathrm{S}}$, gehlenite; in sample $7 \mathrm{~A}: \mathrm{N}_{2} \overline{\mathrm{S}}$, gehlenite and in sample 12: $\mathrm{M}, \mathrm{C}$, natroalunite $\left(\mathrm{NKA}_{6} \overline{\mathrm{S}} \mathrm{H}\right)$, gehlenite.

Missing desirable phases from present trial clinkers probably were compensated by other Mg- mineral formation for example such as diopside $\left(\mathrm{CMS}_{2}\right)$, which can react with $\mathrm{CaCO}_{3}$ and a solid solution between gehleniteåkermanite $\left(\mathrm{C}_{2} \mathrm{~A}(\mathrm{AS})_{2}-\mathrm{C}_{2} \mathrm{MS}_{2}\right)$ results beside $\mathrm{CO}_{2}$ [50]. Gehlenite, a mineral with non-hydraulic features, was outlined in our experimental clinkers. ${ }^{\circ}$

" Koch and Sztrokay authors in the same "Systematic mineralogy" book also wrote, that the higher $\mathrm{Fe}$ and alkali content may promote in the mentioned chemical reaction a melilite group $\left((\mathrm{C}, \mathrm{N}, \mathrm{K})_{2}\left(\mathrm{M}, \mathrm{F}^{2+}, \mathrm{F}^{3+}, \mathrm{A}\right)(\mathrm{S}, \mathrm{A})_{2},\right)$ mineral with lower melting point, down to $\left.1100-1200^{\circ} \mathrm{C}\right)$. 


\section{CONCLUSIONS}

Based on the microscopic investigations and XRD analyses on the experimental clinker samples, it can be concluded that: for all raw material mixtures, heated at temperatures between 1220-1240 ${ }^{\circ} \mathrm{C}$, clinkers containing $\mathrm{C}_{2} \mathrm{~S}, \mathrm{C}_{4} \mathrm{~A}_{3} \overline{\mathrm{S}}, \mathrm{C}_{4} \mathrm{AF}, \mathrm{C} \overline{\mathrm{S}}$ resulted. The microscopic observations on clinker microstructure and mineral grain -size drove to conclusion that clinkers were quenched slowly, affecting the binder quality of cement pastes.

The sulfoaluminate, ensuring the early strength of cement binder, represents a lower percent than in theoretical compositions, but belite contents, imprinting final strength of such binders quantitatively are very close to the theoretical ones. Unfortunately, the stabilised belite polymorphs are not always those with the highest hydraulic properties (ex. sample 12). The ferrite phase, which also should contribute to the final strength of binders, has a lower content than in the theoretical composition. It could also be compensated by minor quantities of aluminosilicates.

Differences between theoretical and experimental mineralogical compositions of clinkers, taking into consideration our observations may be due to: non-reagent grade (main cause), heterogeneous chemical composition of raw meal materials, their impurities quantities which could catalyse or block the same hydraulic mineral formation, heating and slow cooling rate, reducing or oxidizing sintering conditions.

In the current stage of our researches, using the presented raw material mixtures permitted to obtain clinkers with mineralogical compositions, specific for the low energy type belitic clinkers: $C_{2} S=45-50 \%, C_{4} A_{3} \bar{S}=10-12 \%$, $\mathrm{C}_{4} \mathrm{AF}=15-25 \%, \mathrm{C} \overline{\mathrm{S}}=20-22 \%$.

Checking the binder quality, physico- mechanical features of cement pastes or using some additives for improving the cement pastes workability and final strength will be initiated in the next research stage.

\section{EXPERIMENTAL SECTION}

The natural raw materials, used for experimental clinkers, were: Vârghiș limestones, Nucșoara gypsum, Bodoc clays (in samples 1), basaltic scoria from Racoșul de Jos (in sample 7), Filia diatomite (in samples 4, 5, 6, 12) all from Carpathian orocline, mixed with red muds (industrial by-product) from Oradea (in sample 5, 9, 10). The selected raw materials were studied chemically by SEM-EDX (limestone, red mud, diatomite and basaltic scoria) and by wet chemical methods (gypsum and clay) and their compositions were outlined in a previous paper [42]. The mentioned raw materials were used for 12 different clinker recipes. Four recipes (raw material mix samples 2, 
$3,8,11)$ were checked by firing and their experimental data were published in a previous paper [42]. The other recipes (raw material mix samples 1,4 , $5,6,7,9,10,12$ ) were also experimented on and their data represents the topic of the present paper.

The estimation of desirable clinker chemical compositions are based on few SAB cement theoretical mineralogical compositions, counted by reverse Bogue methods $[9,32]$. Such compositions were evidenced in Figure 7 and 8.

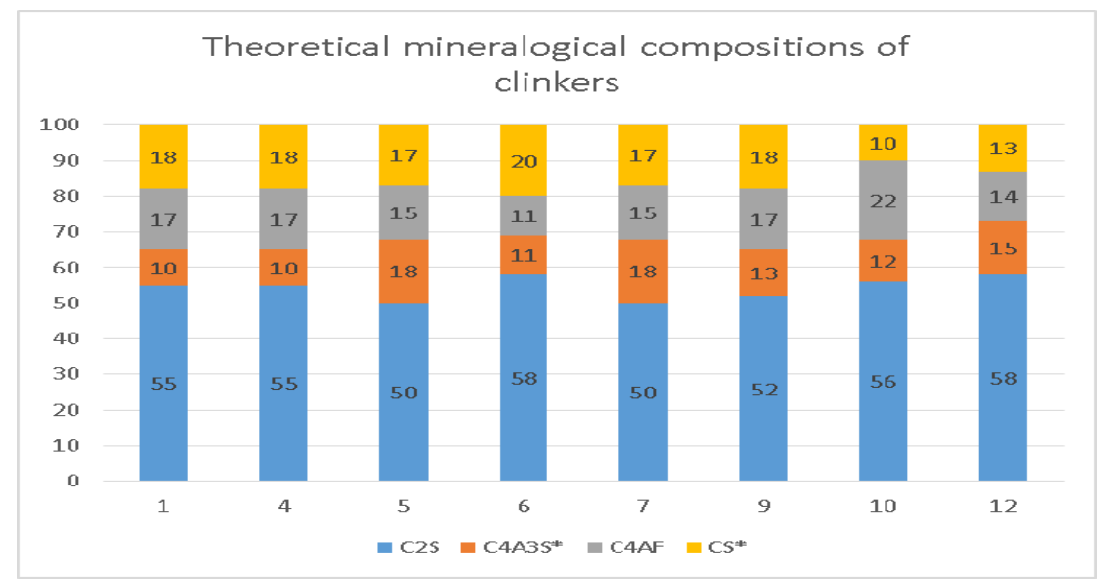

Figure 7. Theoretical mineralogical compositions of few SAB clinkers.

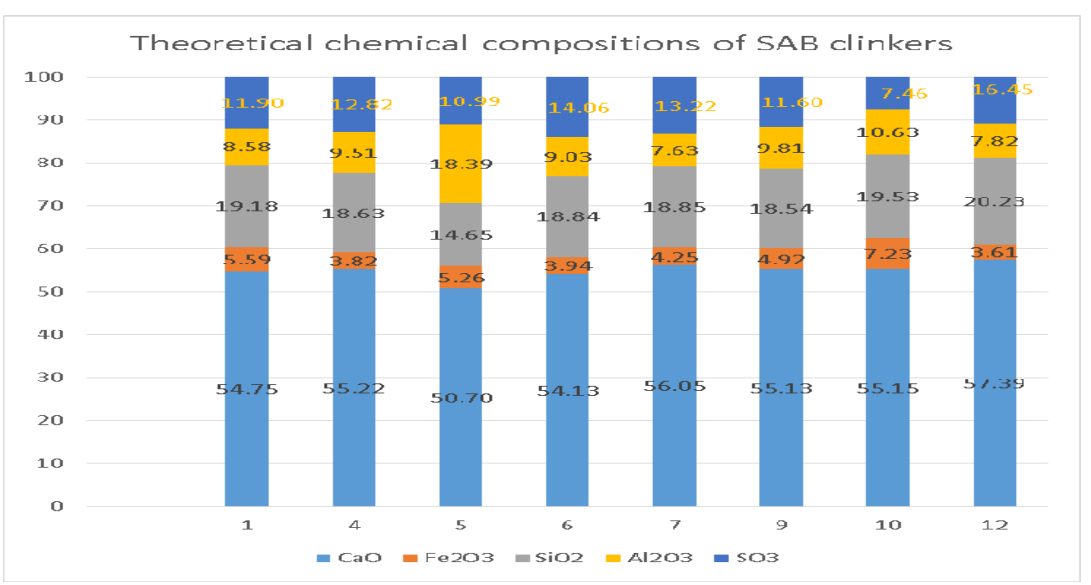

Figure 8. Theoretical chemical compositions of $S A B$ clinkers, based on reverse Bogue counting.

In Figure 9 the used recipes for the feeding material mixtures, submitted for present experiments (recipes of sample $1,4,5,6,7,9,10,12$ ) are outlined. 


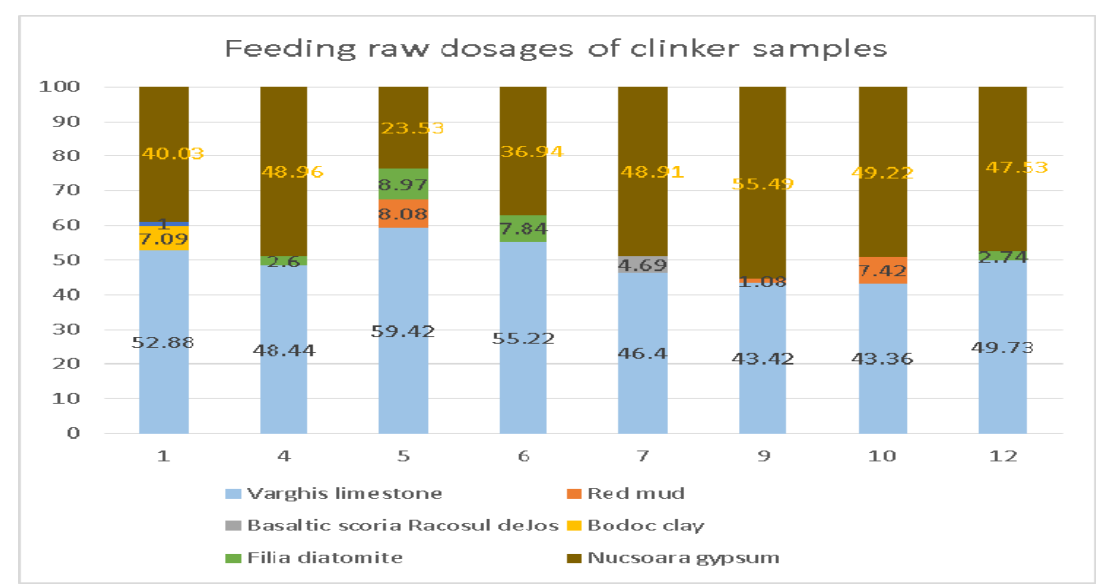

Figure 9. Dosages of raw material mixtures, counted by reverse Bogue method from a theoretical mineralogical composition of SAB clinkers.

The feeding materials were dried in a furnace, grinded in a mill with porcelain balls for two hours then homogenised for one hour. From the milled and homogenised raw mixtures (+ gypsum) cubic briquettes of $25 \mathrm{x}$ $25 \times 25 \mathrm{~mm}$ sizes were shaped, then heated for one hour at peak temperatures (dwell) $1220{ }^{\circ} \mathrm{C}$ and $1240{ }^{\circ} \mathrm{C}$ (the later temperature marked as "A" in clinker sample name from figures 5,6 ) in a laboratory electrical- kiln. The cooling times were 12 hours, using fresh air.

The resulted clinkers were investigated in thin sections (prepared in a laboratory of the Geological Department of Biology and Geology Faculty from Babeș- Bolyai University) under Jenapol optical microscope, in polarised light, by transmission which helped us to assess phase composition and clinker fabric, in order to estimate or improve clinker quality, burning conditions or cooling rate. Microscopic images of thin section images in plane polarized and cross polarized light were taken. The clinkers' mineral phases were also revealed/completed qualitatively and semiquantitatively by XRD method. The XRD powder analyses were performed at the Geology Department of Babeş- Bolyai University, ClujNapoca, by a Brüker D8 Advance diffractometer with Bragg-Brentano geometry, CoKa1 with $\lambda=1.78897, \mathrm{Fe}$ filter and an one-dimensional detector, using corundum (NIST SRM1976a) as internal standard. The data were collected on a $2 \theta=5-64^{\circ}$ interval at a $0.02^{\circ}$, with the measuring step of 0.2 seconds. The assessment of the mineral phases was performed with Match 2.0 software and pdf2 database. 
NEW EXPERIMENTAL SULFOALUMINATE CLINKERS FROM NATURAL RAW MATERIAL MIXTURES

\section{ACKNOWLEDGMENTS}

XRD testing.

The authors deeply acknowledge the work of Dr. Ferenc Forray in

\section{REFERENCES}

1. Y. Wang, M. Su, J. Den, D. Li, Journal of The Chinese Ceramic Society 1982, 04.

2. J. Beretka, M Marroccoli, N. Sherman, G.L. Valenti, Cement and Concrete Researches 1996, 26 (11), 1673.

3. K. Quillin, Cement and Concrete Researches 2001, 31 (9), 1341.

4. A. Alaoui, A. Feraille, A. Steckmeyer, R. Le Roy, 12th International Congress on the Chemistry of Cement 2007.

5. E. Dan, "The low energy cements durability, manufactured with addition of industrial waste materials". Phd thesis, Polytechnic University from Bucharest 2004.

6. C. D. Lawrence, H. J. Sharp, M. Muntean, The 2nd International Symposium of Construction Industry Building Materials and Urban Development, Hanoi 1995, 1.

7. D.C. Lawrence, "Nowel low energy cements based on belite", Brasov, Romania 1996.

8. L. Zhang, M. Su, Y. Wang, Advances in Cement Researches 1999,1:15.

9. I. Soner, "Utilization of Fluidized Bed Combustion Ashes as Raw Material in the Production of a Special Cement", Middle EastTechnical University, Haziran. Turkey 2009.

10. Y. X. Yongmo, G. Chunlei, Advances in Material Researches 2012; 368-373, 478.

11. I. Teoreanu, M. Muntean, Cement and Concret Researches 1983, 13, 711.

12. K.P.Mehta, World Cement Technology 1980, 11 (4), 166.

13. K. P. Mehta, World Cement Technology 1978, 144 (60),11.

14. P. C. Hewlett "Lea's chemistry of cement and concrete". Elsevier ButterworthHeinmann 2004. $1057 \mathrm{p}$.

15. J. H. Sharp, C. D. Lawrencef, R. Yang, Advanced in Cement Researches 1999, 11(1), 3.

16. A. Telesca, M. Marroccoli, M.L. Pace, M.Tomasulo, G.L.Valenti, PJM.Monteiro, Cement and Concrete Composites 2014, 53, 224.

17. M. C. G. Juenger, F. Winnefeld, J. L. Provis, J. H. Ideker, Cement and Concret Researches 2011, 41 (12), 1232.

18. A. Klein, Google Patents 1966.

19. I. Odler, "Improving Energy Efficiency In Portland Clinker Manufacturing", SN Ghosh, Ed. New Delhi, ABI books 1991, 174.

20. I. Odler, "Special Inorganic Cements". First. Taylor and Francis, Ed., London and New York, CRC Press 2000.

21. I. Janotka, L'. Krajči, Ceramics - Silikaty 2002, 46 (3), 110.

22. D. Adolfsson, N. Menad, E. Viggh, B. Björkman, Advances in Cement Researches 2007, 19 (4), 147.

23. I. Janotka, L.Krajči, S.C.Mojumdar, Ceramics - Silikáty 2007, 51 (2), 74.

24. D.C. Popescu. M. Muntean, H.J. Sharp, Cement and Concrete Composites 2003, $25(7), 689$. 
25. A. Alaoui, A. Feraille, A. Steckmeyer, R Le Roy, 12th International Congress on the Chemistry of Cement. 2007, 1.

26. G.L. Valenti. M. Marroccoli. F. Montagnaro. M. Nobili, A. Telesca, Proceedings of the 12th International Congress on the Chemistry of Cement. Montreal, Canada 2007, 1.

27. F.P. Glasser, L. Zhang, Cement and Concret Researches 2001, , 31 (12), 1881.

28. S. Sahu, J. Majling, Cement and Concret Researches 1994, 24 (6), 1065.

29. P. Arjunan. R.M. Silsbee, M.D. Roy, Cement and Concret Researches 1999, 29, 1305.

30. R.B. Jewell, R.F. Rathbone, T.L. Robl, World of Coal Ash Conference, Covington, KY 2007, May(7-10), 18.

31. I. Odler, "Special inorganic cements- Modern Concrete Technology" 8. First, Francis and Taylor, editor, London and New York, E \& FN Spon, 2000, 395 p.

32. I.A. Chen, "Synthesis of Portland Cement and Calcium Sulfoaluminate-Belite Cement for Sustainable Development and Performance". Phd thesis, Texas at Austin 2009.

33. E. Dan, I. Janotka, Ceramics - Silikaty 2003, 47 (4), 141.

34. A. Gies, D. Knofel and M. Bujan, Cement and Concret Researches. 1986, 16 (c), 411.

35. A. K. Chatterjee, Proceedings of 11th International Congress on the Chemistry of Cement, Durban, South Africa 2003, 31.

36. T. Staněk, P. Sulovský, Cement and Concret Researches 2015, 68, 203.

37. Tongbo Sui, Lei Fan, Zhaijun Wen, Jing Wang, Journal of Civil Engineer Architure 2015, 9 (4), 384.

38. E.M. Gartner, D.E. Macphee, Cement and Concret Researches 2011, 41 (7), 736.

39. E. M. Gartner, Cement and Concret Researches 2004, 34(9), 1489.

40. E. M. Gartner, C. Comparet, B. Albert, A.M. Dunster, International Cement Rev. 2014, 1067, 107.

41. B. Lothenbach, B. Albert, V. Morin, E.M. Gartner, 14th International Congress on Chemistry and Cement 2015, (October).

42. E. Mosonyi, M. Spataru, T. Halmagyi, Studia UBB Chemia 2016, LXI/ 4, 163.

43. H. Insley, Journal of Research of the National Bureau of Standards 1936, 17 (3), 353.

44. Y. Ono, Proceedings of the Third Annual International Conference On Cement Microscopy, Houston, Texas, USA, International Cement Microscopy Association 1981, 198.

45. B.Tavasci, Cement 1978, 3, 363.

46. D. H. Campbell, "Microscopical Examination and Interpretation of Portland Cement and Clinker". Second, Natalie C. Holz AEPCA, editor, Portland Cement Association, Skokie, IL, USA, Portland Cement Association 1999, $201 \mathrm{p}$

47. F. Bullerjahn, International Congress on the Chemistry of Cement 2015, (October).

48. F. H. Chung, Journal of Applied Crystallography 1974, 7 (6), 519.

49. P. M. de Wolff, J. Visser,. Powder Diffraction 1988, 3, 202.

50. S. Koch, K. I. Sztrókay, "Ásványtan II", Athenaeum Nyomda Nemzeti Tankönyvkiadó, M. Glasner, Ed., Budapest, 1968, 675. 